\title{
Fluorides in Wastewater Discharges: Toxic Challenges to the St. Lawrence River Biological Community
}

\author{
Peggy Wallis, ${ }^{1}$ Ronald GeHR ${ }^{2}$ and Perry Anderson ${ }^{1}$
}

${ }^{1}$ Ecotoxicology and Environmental Chemistry Research Unit, Concordia University, Montreal, Quebec H3G 1 M8

2Department of Civil Engineering, McGill University, Montreal, Quebec H3A 2K6

\begin{abstract}
This literature review examines the risk to fluvial organisms of fluoride released to the St. Lawrence River by the Montréal Urban Community wastewater treatment plant. The following key points are presented regarding the behaviour of fluoride in aquatic systems: fluoride is not removed by primary sewage treatment methods; fluoride from the treatment plant is rapidly diluted to background levels; aquatic plants do not accumulate significant levels of fluoride; fluoride is generally sequestered in the shell/exoskeleton/skeleton and skin of animals and released via the urinary system; fluoride ion is not very toxic in aquatic systems; there is rarely a large difference between acute and chronic (or lethal and sublethal) threshold levels of fluoride in aquatic systems; the most sensitive aquatic organisms are trout and fingernail clams; finally, the only significant evidence of synergistic action is with aluminium. It is concluded that fluoridation of the city of Montreal's drinking water would not pose any significant additional risk to the biological community in the receiving waters of the St. Lawrence River.
\end{abstract}

\section{Introduction}

Drinking water fluoridation has been a contentious issue since it was first introduced in North America in 1945, and remains so each time a municipality considers it (Moolenburgh 1987; Belair and Viau 1988; Colquhoun 1994). This report has its origins in the public consultations conducted by the city of Montréal concerning a possible fluoridation project. Questions were raised concerning the risk of impact on the biological community of the St. Lawrence River downstream from the outfall of the Montréal sewage treatment plant, due to the resultant low levels of fluoride (Ville de Montréal 1988). Subsequent studies at the treatment plant indicated considerable fluctuation in existing daily and seasonal fluoride levels (Gehr and Leduc 1992; Choueiri et al. 1995), partially due to industrial discharges.

In conducting an ecotoxicological risk assessment, it is necessary to examine three types of information (Pascoe 1993). (1) Ecological: the organisms and communities present that may be or have been impacted by the presence of the compound under study. (2) Chemical: the properties of the compound which affect its presence and movement within the ecosystem. (3) Toxicological: the nature and degree of dysfunction caused 
by the compound's contact with the organisms of concern. An evaluation of risk can then be made by determining the availability of the compound and its toxicity to the ecosystem due to exposure over time.

The structure of this review is thus an examination of the biological resources present, the chemical and physical properties of fluoride, its abiotic transport and distribution, its toxicokinetics (the absorption, accumulation, biotransformation and elimination of fluoride within target organisms), and its toxicodynamics (effective concentrations and mechanisms of action). At the end of each section, the key point(s) relevant to the assessment of risk are highlighted. Having presented all this information, the final section evaluates the risk of damage. The conclusions have been expanded to cover possible consequences of the total fluoride load rather than just the additional loading consequent to water fluoridation by the city of Montréal.

It is important to be aware that fluoride is also considered to be a significant air pollutant, arising primarily from aluminum and phosphate production plants. Consequently, much of the information pertaining to toxicological effects is based on terrestrial systems (e.g., WHO 1985; CCE 1986; Government of Canada 1993). Where possible, data have been extrapolated to the aquatic environment.

\section{Biological Resources in the Area of Study}

Because of rapid currents and heavy shipping traffic in the immediate receiving waters of Montréal's municipal effluent discharge, the community of organisms likely to come into contact with elevated fluoride levels in the treatment plant's plume (Fig. 1) is small. Pilon et al. (1980) have reported that at the river border next to Île Sainte-Therèse, there exists an annuai community of submerged macrophytes, primarily filamentous Potamogeton pectinatus, and some grass-like Alisma gramineum. Close to shore, there are emergent bullrushes (Typha angustifolia) and reeds (Scirpus americanus, S. acutus and S. validus). This zone of plant growth is not stable or calm enough to serve as a spawning ground or "nursery" for local fish species, although older fish may occasionally use the weed bed as cover.

The only benthic organisms identified were immature oligochaete worms (Tubificidae), considered indicators of polluted water, and one species of amphipod, Gammarus gammarus. The density of individuals, $52 / \mathrm{m}^{2}$, and the index of species diversity, 0.81 , are considered low. Nothing was reported concerning populations of bacteria, algae or protozoans, the organisms of "biological self-purification" that form the basis of the food chain.

Fish species common to this sector of the St. Law rence River generally prefer quieter waters to those of the receiving waters, although they may venture into the plume of the municipal waste from time to time. They include northern pike (Esox lucius), yellow perch (Perca flavescens), 


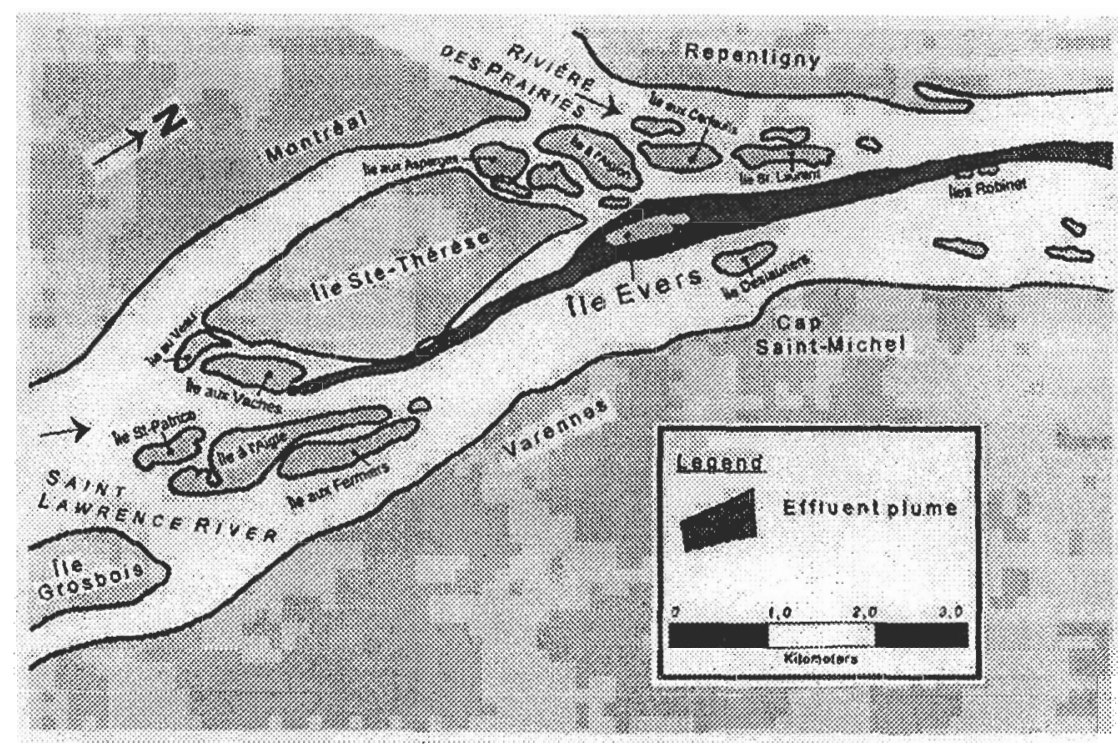

Fig. 1. Map of the area of study showing a typical effluent plume, as defined by rhodamine studies (adapted from Boulanger 1984).

largemouth bass (Micropterus salmoides), brown bullhead (Ictalurus nebulosus), golden shiner (Notemigonus crysolencas), carp (Cyrinus carpio), pumpkinseed (Lepomis gibbosus), black crappie (Pomoxis nigromaculatus), bowfin (Amia calva), and central mudminnow (Umbra limi) (Pilon et al. 1980). Also, both the eel (Anguilla bostoniensis) and sea lamprey (Petromyzon marinus) use the St. Lawrence as a migratory route (Hubbs and Lagler 1964) and may pass through this area, although no official record of them in the zone of concern was found.

Some members of the bird population may be at risk, particularly the shorebirds and surface-feeding ducks that consume plants and small invertebrates living in the outflow plume. Fish-eating species may be at lower risk, as their prey is probably less regularly exposed to the fluoridebearing plume. Table 1 shows the species with aquatic feeding habits that have been observed in the area. Of note is the small colony of rare Wilson's phalarope (Steganopus tricolor) that nests on Île Evers, directly in the path of the plume. Île Sainte-Thérèse and smaller downstream islands are important rest sites on the migratory routes of many other species (Pilon et al. 1980).

The only local mammal likely to be at risk is the muskrat (Ondatra zibethica), which spends much of its time in the water and whose food source is primarily aquatic. Raccoons (Procyon lotor) might conceivably be exposed if the aquatic proportion of their diet is large.

This area was considered polluted before the treatment plant commenced operation (Gravel and Pageau 1979). The effect of removing numerous raw sewage outlets upstream and replacing them with the single, 
Table 1. List of the bird species with aquatic feeding habits that have been observed in the area of study (adapted from Pilon et al. 1980, feeding habits from Peterson 1980)

\begin{tabular}{|c|c|c|}
\hline Common name & Scientific name & Food \\
\hline Pied-billed Grebe & Podilymbus podiceps & Small fish, invertebrates, tadpoles \\
\hline $\begin{array}{l}\text { Double-crested } \\
\text { Cormorant }\end{array}$ & Phalacrocorax auritus & Fish, crustaceans \\
\hline Great Blue Heron & Ardea herodias & Fish, amphibians,crayfish, insects \\
\hline Green Heron & Butorides striatus & Fish, amphibians, invertebrates \\
\hline Snowy Egret & Egretta thula & Fish, amphibians, invertebrates \\
\hline $\begin{array}{c}\text { Black-crowned } \\
\text { Night Heron }\end{array}$ & Nycticorax nycticorax & Fish, amphibians, invertebrates \\
\hline American Bittern & Botaurus lentiginosus & Fish, amphibians, invertebrates \\
\hline Glossy Ibis & Plegadis falcinellus & Small fish, invertebrates \\
\hline Canada Goose & Branta canadensis & Vegetation \\
\hline Snow Goose & Chen caerulescens & Vegetation \\
\hline Mallard Duck & Anas platyrhynchos & Vegetation, invertebrates \\
\hline Black Duck & Anas rubripes & Vegetation, invertebrates \\
\hline Gadwall & Anas strepera & Vegetation, invertebrates \\
\hline American Widgeon & Anas americana & Vegetation, invertebrates \\
\hline Common Pintail & Anas acuta & Vegetation, invertebrates \\
\hline Green-winged Teal & Anas crecca & Vegetation, invertebrates \\
\hline Blue-winged Teal & Anas discors & Vegetation, invertebrates \\
\hline Northern Shoveler & Anas clypeata & Vegetation, invertebrates \\
\hline Osprey & Pandion haliaetus & Fish \\
\hline Common Gallinule & Gallinula chloropus & Invertebrates \\
\hline Killdeer & Charadrius vociferus & Invertebrates, vegetation \\
\hline Common Snipe & Capella gallinago & lnvertebrates, vegetation \\
\hline Spotted Sandpiper & Actitis macularia & Invertebrates \\
\hline Greater Yellowlegs & Tringa nelanoleuca & Invertebrates \\
\hline Lesser Yellowlegs & Tringa flavipes & Invertebrates \\
\hline Least Sandpiper & Calidris minutilla & Invertebrates \\
\hline Dunlin & Calidris alpina & Invertebrates \\
\hline Sanderling & Calidris alba & Invertebrates \\
\hline Marbled Goodwit & Liniosa fedoa & lnvertebrates \\
\hline Wilson's Phalarope & Steganopus tricolor & Insect larvae, invertebrates, plankton \\
\hline $\begin{array}{l}\text { Greater Black- } \\
\text { backed Gull }\end{array}$ & Larts marinus & Fish, invertebrates, vegetation, carrion \\
\hline Herring Gull & Larus argentatus & Fish, invertebrates, vegetation, carrion \\
\hline Ring-billed Gull & Larus delawarensis & Fish, invertebrates, vegetation, carrion \\
\hline Bonaparte's Gull & Larus philadelphia & Fish, invertebrates, vegetation, carrion \\
\hline Common Tern & Sterna hirundo & Small fish, large invertebrates \\
\hline Black Tern & Chlidonias niger & Small fish, large invertebrates \\
\hline Belted Kingfisher & Megaceryle alcyon & Fish \\
\hline
\end{tabular}


treated sewage outlet at this location is difficult to state. The plants and benthic organisms in the most highly impacted zone are pollution-tolerant species. They may still be at some risk of fluoride accumulation and toxic effects. The remaining animals in the area are unlikely to spend much time in the treatment plant plume, as it is in a highly turbulent area. Direct exposure will thus be minimized for such organisms, and their food sources will be the main route of exposure, assuming that fluoride is subject to biomagnification.

Key point: The biological resources at risk of direct effects by fluoride are minimal.

\section{Chemical and Physical Properties}

The fluoride ion is the smallest of the halides (1.33 angstroms ionic radius, $19.00 \mathrm{~g} /$ mole molecular weight) and, as such, the most electronegative (Bank and Goldwhite 1966; Weast 1984). It has the potential to be highly reactive, either by attracting an electron to fill the $2 \mathrm{p}$ valency shell or, less commonly, by donating an electron pair in an unsaturated system. It forms strikingly strong hydrogen bonds with water (Diercksen et al. 1975), carboxylates and amides (Emsley et al. 1981) as well as very stable polar covalent bonds with carbon. The facility for hydrogen bond formation explains the stability of the ion in aqueous solution, where it holds five water molecules per ion, and its high hydration energy (the amount of energy required to remove the ion from water). Its behaviour in real and model biological systems differs distinctly from other halides and most polyatomic anions (Wright and Diamond 1977). Because of its small ionic radius, it potentially has a high capacity to denature proteins and other essential biological molecules (Wiseman 1970). These features justify a concern for the welfare of organisms exposed to fluoride.

Key point: The fluoride ion in solution forms stable hydrogen bonds with five water molecules.

\section{Transport and Distribution}

Much research has been done on the transport and distribution of gaseous and particulate fluorides in air (e.g., Ouellet et al.1983), and some research exists on high concentrations of fluoride released in industrial effluents (e.g., Damkaer and Dey 1989; Camargo 1992), but municipal sources such as this study examines have generally been ignored (Davies 1989; Foulkes and Anderson 1994). The work that has been done indicates that (1) primary sewage treatment does not remove fluorides from water (Gehr and Leduc 1992), although secondary treatment can reduce concentrations by as much as $70 \%$ (Masuda 1964); (2) the concentration of fluoride (and most other contaminants) entering the receiving waters of the St. Lawrence River is diluted to the background level of $0.2 \mathrm{mg} \mathrm{F}-/ \mathrm{L}$ 
(Choueiri et al. 1995) within $2 \mathrm{~km}$ (Boulanger 1984; Chu et al. 1991) (smaller, cleaner rivers may, however, be significantly affected even $20 \mathrm{~km}$ downstream [Camargo et al. 1992b]); (3) half the fluoride added to quiet waters is removed to other environmental compartments, mostly to sediment, in 0.6 day (Kudo and Garrec 1983); (4) fluoride levels in sewage are elevated even when water is not fluoridated (industries discharging into municipal sewage systems as well as runoff from contaminated rain and snow can make considerable contributions [Ouellet et al. 1983; Choueiri et al. 1995]); and (5) the fluoride flux in the St. Lawrence River would increase by $1.2 \%$ if Montréal were to fluoridate its drinking water (Gehr and Leduc 1992).

Fluoride ions may be removed from water when that water is applied to soil by processes similar to those used in wastewater treatment (e.g., Patterson 1985). This is of interest since drinking water is also used for such purposes as watering gardens and lawns, and washing vehicles and buildings. The runoff eventually reaches the treatment plant via storm sewers. At the interface between water and soil, fluoride reacts in a variety of competing chemical equilibria dependent on $\mathrm{pH}$, temperature, particulate organic carbon, clay content (Pickering 1985; Baars et al. 1987) and basic soil type (Wilke 1987). A simple statement about the fate and effects of fluorides in soil is therefore difficult. Two potential events are worth noting, though. Calcium fluoride $\left(\mathrm{CaF}_{2}\right)$ may arise where high calcium-based substrates exist, but this formation requires a fluoride ion concentration of at least $9.5 \mathrm{mg} / \mathrm{L}$, almost 10 times higher than levels achieved in drinking water. Gibson et al. (1992) showed that approximately $75 \%$ of fluoride applied to an oxisol was simply sorbed by the soil particles. However, aluminium ions, soluble organo-aluminium complexes and alumino-fluoride compounds of the general formula $\left[\mathrm{AlF}_{n}\left(\mathrm{H}_{2} \mathrm{O}\right)_{6-n}\right]^{(3-n)+}(\mathrm{n}=1-6)$ are released from clays and organic matter at low fluoride concentrations. This mobilization follows hydroxyl replacement and subsequent crystal lattice breakdown of substrates in the presence of waterborne fluoride (Slavek et al. 1984; Elrashidi and Lindsay 1987; Pickering et al. 1988; Gibson et al. 1992). The release of aluminium from soil particles in the form of soluble complexes, a fluoride property, may be of concern in that it may contribute to a joint effect in waters already receiving enhanced levels of aluminium as a consequence of acid precipitation (Neal 1989). The aluminium-mobilizing action of fluoride may also apply to St. Lawrence River sediments, where aluminium levels of $60,000 \mu \mathrm{g} / \mathrm{g}$ and more have been detected, and to suspended solids in the water column, where aluminium concentrations may reach $1.41 \mathrm{mg} / \mathrm{L}$ (Sloterdijk 1988).

Water quality characteristics which may have a significant effect on the fate of fluorides include hardness or alkalinity (as $\mathrm{CaCO}_{3}$ ), $\mathrm{pH}$ and temperature. As noted for soils, calcium may precipitate fluoride ions as insoluble $\mathrm{CaF}_{2}$. The St. Lawrence River in the area of the receiving waters has been reported to have a hardness in the range of 52 to $105 \mathrm{mg} / \mathrm{L}$ as $\mathrm{CaCO}_{3}$ (moderately hard). $\mathrm{pH}$ is an important factor affecting the speci- 
ation of total fluoride present. The St. Lawrence has a $\mathrm{pH}$ of 7.8 to 8.1 (Sloterdijk 1988). Temperatures in the receiving waters range from $0^{\circ} \mathrm{C}$ in winter to $20^{\circ} \mathrm{C}$ in summer. The level of suspended solids in the effluent, as well as in the river, is also a factor, as fluoride ions may be adsorbed by organic material or fine clay particles. These materials, as they settle out, can contribute considerably to fluoride levels in sediments (Gordon and Tourangeau 1977; Kudo and Garrec 1983).

Key points: (i) Fluoride is not removed by primary sewage treatment methods. (ii) Fluoride entering the St. Lawrence at the treatment plant outlet is rapidly diluted to background levels. (iii) Fluoride ions added to soil or sediment may mobilize aluminium in the form of soluble complexes.

\section{Toxicokinetics}

\section{Adsorption/Accumulation/Elimination}

\section{Plants}

Terrestrial plants have been shown to accumulate fluoride, mainly by adsorption through the leaves from gaseous and particulate air pollution, although some uptake occurs through the roots from contaminated soils (Weinstein 1977; Andrews et al. 1989; Machoy and Machoy-Mokrzyńska 1990). Fluorides can also be absorbed from irrigation water, particularly if it is sprayed on leaves, and directly from the water in flooded salt marshes (Baars et al. 1987) and in hydroponic systems, as fluoride ions can diffuse easily across epithelial membranes (Weinstein 1977).

There are fewer studies available on the fate of fluorides in aquatic plants. Freshwater algae and plants do accumulate fluorides but generally at rates much below that of terrestrial plants, and steady-state tissue concentrations of fluorides appear to be reached quickly (Bundock et al. 1982). Chaisemartin (1985) reported a plateau in the rate of fluoride fixation in the macrophyte Rannuculus aquatilis exposed to $10 \mathrm{mg} \mathrm{F}^{-} / \mathrm{L}$, after 8 hours. This aquatic species is known to be pollution-tolerant and is thought to effectively depurate fluoride, a capacity not generally available to terrestrial plants. Duckweed (Spirodela polyrrhiza) growing in freshwater ponds with fluoride concentrations between 0.5 and $1.0 \mathrm{mg} / \mathrm{L}$ had a fluoride content of roughly $35 \mu \mathrm{g} / \mathrm{g}$ dry weight, as did fronds from unpolluted waters used in laboratory studies. Significant accumulation occurred at and above $5 \mathrm{mg} \mathrm{F}$ - $/ \mathrm{L}$, reaching plateau levels 40 times the exposure concentration in 3 to 5 days (Shire and Chandra 1991). The aquatic liverwort Scapania undulata increased fluoride content 21 to $67 \%$ when exposed to $250 \mathrm{mg} \mathrm{F}$ / $/ \mathrm{L}$. The actual degree of accumulation was dependent on the fluoride level in the water from which the liverwort had been collected, with less fluoride being accumulated by those plants from sources with higher fluoride concentrations (Samecka-Cymerman and Kempers 1990). 
Nichol et al. (1987) found that the cells of the chlorophyte algae Chlorella pyrenoidosa did not take up fluoride even at $150 \mathrm{mg} \mathrm{F-/L.} \mathrm{A}$ cyanophy te species of algae, Synechococcus leopoliensis, was found to accumulate fluoride temporarily at $\mathrm{pH} 6.26$ but not at $\mathrm{pH}$ 6.88. Fluoride was released rapidly (half-life 10 to $20 \mathrm{~min}$ ) when cells were placed in fluoridefree growth medium. When pre-exposed to nontoxic levels of fluoride, $S$. leopoliensis was shown to adapt, possibly by increasing the permeability of the cell wall to $\mathrm{F}^{-}$, thereby reducing or preventing accumulation on subsequent exposure to normally toxic levels (Nichol et al. 1987).

While some marine algal species do appear to accumulate fluoride even at the normal $1.0 \mathrm{mg} \mathrm{F}$-/L level in seawater (Groth 1975), Hemens and Warwick (1972) found no accumulation by either Cladophora algae or eel grass (Zostera capensis) at $52 \mathrm{mg} \mathrm{F}$-/L for 72 days.

It has been suggested that fluoride initially enters aquatic plant cells or crosses cellular membranes as the molecule HF. The uptake of waterborne fluoride has been shown to increase for some algae at lower ambient $\mathrm{pH}$, where the concentration of HF is higher (Nichol et al. 1987).

Key point: Aquatic plants do not accumulate significant levels of fluoride, either because they do not absorb the hydrated ion or because they can effectively depurate it.

\section{Invertebrates}

It has been inferred that terrestrial invertebrates accumulate high body burdens of fluoride from the food chain (i.e., Buse 1986). In the aquatic environment, Gordon and Tourangeau (1977) reported elevated, although declining, fluoride levels in aquatic insects (up to $243 \mu \mathrm{g} \mathrm{F}-/ \mathrm{g}$ ) even 9 years after the shutdown of a phosphate plant that had discharged effluent to the stream. The water level was only $0.2 \mathrm{mg} \mathrm{F}-/ \mathrm{L}$, but sediments still contained large amounts of fluoride, supporting the biomagnification concept. Chaisemartin (1985) studied an experimental food chain with a pollution-tolerant macrophyte, an herbivorous snail (Lymnaea peregra) and its predator, a crayfish (Oronectes limosus). Bioaccumulation ratios were low, only 0.49 to 0.86 for the crayfish at $10 \mathrm{mg}$ $\mathrm{F}$-/L exposure, and snails artificially loaded with fluoride seemed to contribute little to the total body burden of the crayfish. Levels of fluoride in the crayfish exoskeleton were 6 to 10 times higher than those in gills or muscles, with greater accumulation noted in warmer temperatures. Unlike the algae, previously contaminated organisms accumulated up to 10 times more fluoride than ones from clean environments. It was concluded that accumulation involved the complex interaction of biotic and abiotic factors.

In a preliminary study, Mane and Pillai (1985) found no significant correlation between fluoride concentration in river water $(0.47$ to $0.58 \mathrm{mg}$ $\mathrm{F}-/ \mathrm{L}$ ) and fluoride levels in the flesh of three bivalve mollusc species living in the river. Unfortunately, they did not determine levels in the shells, but fiesh levels were quite low, less than $0.05 \mu \mathrm{g} \mathrm{F} / \mathrm{g}$ (wet weight). They did note a possible relationship between body length (and therefore vol- 
ume of water processed) and fluoride content. Kudo and Garrec (1983) reported bioaccumulation factors of 11 to 85 in molluscs exposed to ammonium fluoride in an experimental pond. The fluoride had a biological half-life of 43 days.

Fluoride kinetic studies on marine and estuarine invertebrates have been more extensive than in fresh water, but because fluoride levels in seawater are naturally in the $1 \mathrm{mg} \mathrm{F}$ - $/ \mathrm{L}$ range and the organisms are physiologically adapted to a high halide environment, the conclusions drawn may be suspect when applied to freshwater systems. Hemens and Warwick (1972) found that mud crab (Tylodiplax blephariskios), sand shrimp (Palaemon pacificus) and prawn (Penaeus indicus) accumulate fluoride primarily from the water, with factors of whole body accumulation in $52 \mathrm{mg} \mathrm{F}-/ \mathrm{L}$ water ranging from 8 to 30 times. Wright and Davison (1975) confirmed this for crab (Carcinus maenas) at $30 \mathrm{mg} \mathrm{F}-/ \mathrm{L}(10-25 \mathrm{X}$ ), although accumulations were much lower at $10 \mathrm{mg} \mathrm{F}^{-} / \mathrm{L}$ and negligible at $1 \mathrm{mg} \mathrm{F}^{-} / \mathrm{L}$. They distinguished between storage in the exoskeleton and buildup in various soft tissues, with muscle and haemolymph simply reflecting ambient fluoride levels. Interestingly, a short-term experiment with mussels (Mytilus edulis) showed a similar accumulation factor in the shell (20X), but the soft tissue concentration increased by a factor of roughly 100 , with levels exceeding that of the shell in some cases. They suggested that this unusual pattern is due to the large volumes of seawater processed by these sessile filter feeders. Barbaro et al. (1981) also found molluscs to accumulate fluoride far above ambient levels (20-70X) in soft tissues, with a clear relationship between exposure level and tissue concentration.

Moore (1971) provided detailed information on fluoride kinetics in the blue crab (Callinectes sapidus), demonstrating preferential uptake by the exoskeleton in terms of both absolute levels and rate of uptake, in comparison to gills, hepatopancreas and muscle. At $2 \mathrm{mg} \mathrm{F}^{-} / \mathrm{L}$ for 30 days, however, even the exoskeleton did not show significant concentration. Fluoride release, once the crabs were removed from exposure, was only slightly slower than uptake and occurred in all tissues, including the exoskeleton. McClurg (1984) reported similar results for the prawn (Penaeus indicus) and suggested that the shedding of the exoskeleton (ecdysis) may be a mechanism for reducing fluoride content. Antarctic krill accumulate as much as 3,300 $\mu \mathrm{g} \mathrm{F}^{-} / \mathrm{g}$ in the cuticle but less than $1 \mu \mathrm{g} \mathrm{F}^{-} / \mathrm{g}$ in the other tissues. When the krill is killed, however, the fluoride rapidly translocates from the cuticle to the soft tissues (Landy et al. 1991).

Key points: (i) Invertebrates generally cope effectively with fluoride by accumulating it in the exoskeleton or shell. (ii) Ecdysis provides invertebrates with a means of eliminating excess fluoride completely.

\section{Fish}

Neuhold and Sigler (1960) demonstrated that the fluoride uptake rate in rainbow trout (Salmo gairdneri) and carp (Cyrinus carpio) was related to fluoride content in water as well as duration of exposure. In muscle 
tissue, low exposure levels in soft water produced an average concentration of $2.95 \mu \mathrm{g} \mathrm{F}^{-} / \mathrm{g}$, but the presence of small bones in the flesh led to high variability in determinations. Exposure to higher levels (i.e., $25 \mathrm{mg} \mathrm{F} / \mathrm{L}$ ) produced a sevenfold increase in tissue concentrations. In osseous tissue (cancellous and skeletal bone), the double reciprocal plot of uptake rate ( $\mu \mathrm{g} \mathrm{F}^{-} / \mathrm{g} /$ hour) versus medium concentration $(\mathrm{mg} \mathrm{F}-/ \mathrm{L}$ ) gave equations typical of second order, enzyme-mediated reactions. Brown trout from a natural population exposed to as much as $14 \mathrm{mg} \mathrm{F}^{-} / \mathrm{L}$ showed a linear relationship between bone concentration and body length (hence, age), suggesting a relatively continuous retention of fluoride over time. Fluoride in skeletal bone reached higher levels $(>1,500 \mu \mathrm{g} \mathrm{F} / \mathrm{g}$ ) than cancellous bone (approximately 1,000 $\mathrm{g} \mathrm{F}^{-} / \mathrm{g}$ ) for rainbow trout and they accumulated fluoride faster than did the pollution-tolerant carp. The increase in mucous cells in the gills at low fluoride concentrations and in the skin of the head at high levels suggest that rainbow trout make some attempt to regulate fluoride using their chloride-secreting mechanism. Trout eggs showed an uptake rate pattern similar to that of bone. Gordon and Tourangeau (1977) reported preferential accumulation of fluoride in the bone $(1,351 \mu \mathrm{g} \mathrm{F} / \mathrm{g})$ of three trout species in a previously contaminated stream; skin contained $146 \mu \mathrm{g} \mathrm{F}^{-} / \mathrm{g}$ and muscle only $8.7 \mu \mathrm{g} \mathrm{F}-\mathrm{g}$. A similar pattern was reported for tilapia fish (Oreochromis leucostictus) living in water containing $2.4 \mathrm{mg} \mathrm{F}^{-} / \mathrm{L}$. Only the bone concentration showed a relationship with fish weight, suggesting that the soft tissues have a saturation level or a fluoride excretion mechanism (Gikunju 1992). Kudo and Garrec (1983) reported accumulation factors of 9 to 32 times in carp exposed to ammonium fluoride in an experimental pond.

Christensen's (1987) comparison of a river-dwelling population of Arctic char (Salvelinus alpinus) exposed to from 5 to $20 \mathrm{mg} \mathrm{F}^{-} / \mathrm{L}$ to a nearby anadromous population showed that, like invertebrates, this species is capable of releasing accumulated fluoride. It is possible that the physiological changes involved in moving from fresh to salt water are responsible for mobilizing the fluoride. As with trout, bone held higher concentrations $\left(1,150 \mu \mathrm{g} \mathrm{F}^{-} / \mathrm{g}\right)$ than muscle $(16 \mu \mathrm{g} \mathrm{F} / \mathrm{g})$. He cited a study that indicated uptake in fish can occur from food as well as from water. Note that fish actually ingest very little water, so uptake from water must be primarily across the gills during respiration. Rainbow trout have been shown to accumulate ingested fluoride in their skeletal tissues, tolerating as much as $2,250 \mu \mathrm{g} \mathrm{F}^{-} / \mathrm{g}$ sodium fluoride in their feed. Fluoride is readily available to salmonids fed krill and other marine organisms (Landy et al. 1991).

Wright (1977) showed that fluoride uptake in brown trout fry (Salmo trutta) tended to reach a plateau after 8 days, even at $20 \mathrm{mg} \mathrm{F} / \mathrm{L}$. The concentration factor at $5 \mathrm{mg} \mathrm{F}-/ \mathrm{L}$ was 2.3. Pillai and Mane (1985) demonstrated that the fry of Catla catla, a tropical fish, accumulate fluoride from an effluent in a fashion directly proportional to effluent concentration and length of exposure. Catla catla eggs have also been shown to accumulate fluoride (Pillai and Mane 1984).

In the marine environment, Hemens and Warwick (1972) showed 
that the mullet (Mugil cephalus) accumulates significant (55X) fluoride at $52 \mathrm{mg} \mathrm{F}^{-} / \mathrm{L}$. This accumulation factor is much higher than those of the accompanying invertebrates in their experimental ecosystem and suggests that the omnivorous mullet may have gained some of its fluoride from its food. Wright and Davison (1975) found that the axial skeleton concentrated far more fluoride (20 to $100 \mu \mathrm{g} \mathrm{F}-/ \mathrm{g}$ [wet weight]) than any of the other tissues in a variety of fish species, but the data were too variable to show differences between fish caught near the contaminant source and those caught in the open ocean. Fish skin also concentrated fluoride to some degree (10 to $50 \mu \mathrm{g} \mathrm{F} / \mathrm{g}$ [wet weight]). High fluoride content in food (mainly crustaceans) from stomachs of some cod (Gadus morrhua) contributed to elevated levels $(20 \mu \mathrm{g} \mathrm{F}-/ \mathrm{g}$ [wet weight]) in their stomach walls. One haddock (Gadus aeglifinus) from near the source had an extremely high level in its gill bar (100 $\mu \mathrm{g} \mathrm{F} / \mathrm{g}$ [wet weight]) and skin (75 $\mu \mathrm{g} \mathrm{F-/g} \mathrm{[wet} \mathrm{weight]).} \mathrm{Mudskipper} \mathrm{(Boleophthalmus} \mathrm{dussumieri)} \mathrm{accu-}$ mulated very little fluoride in intestine, muscle and liver during the first 48 hours of exposure to $5 \mathrm{mg} \mathrm{F}-/ \mathrm{L}$, but continued exposure lead to levels as high as the $50 \mathrm{mg} \mathrm{F}^{-} / \mathrm{L}$ animals. After 10 days, however, the fluoride levels at all exposures had dropped, suggesting that the soft tissues of this species have the ability to release fluoride. Whether it was sequestered in the skeleton or eliminated entirely from the body was not determined (Shaikh 1986).

Key points: (i) Fish may accumulate higher levels of fluoride than invertebrates, from food as well as water. (ii) Fluoride in fish is generally sequestered in the skeleton and skin.

\section{Mammals}

The only information pertaining to fluoride in aquatic mammals refers to ocean-going species, i.e., fin whales and crabeater seals, both of which prey on krill. Extremely high levels of fluoride have been reported in the bones of these animals $(3,070-18,570 \mu \mathrm{g} \mathrm{F}-/ \mathrm{g})$ without any apparent negative effect (Landy et al. 1991). Terrestrial mammalian species have been studied extensively. Fluoride ion appears to be absorbed fairly rapidly (half-life in stomach 30 minutes) and efficiently ( $85 \%$ plateau at 2 hours) by the mammalian digestive tract, with the kinetics of a typical first-order reaction (Smith 1966b). Whitford and Pashley (1984) presented evidence that absorption was principally as the undissociated molecule $\mathrm{HF}$, not the fluoride ion itself, at the normal stomach $\mathrm{pH}$ of 2.1. Some absorption also occurs from the small intestine, where it has been suggested that the hydrated fluoride ion can successfully pass through paracellular channels (Nopakun and Messer 1990). The presence of calcium or aluminum ions reduces gastrointestinal absorption, presumably by forming insoluble complexes that do not easily cross membranes (Hodge and Smith 1965).

When uptake rates into blood are examined, efficiency is in the order of $2 \%$ per minute, which is low when considering water passing over gills as the major absorption route in fish. Soft tissue content generally reflects the blood concentration, equilibrating in 15 to 60 minutes, depending on the 
blood supply to the tissue. Normal tissue levels range from 0.1 to $1 \mu \mathrm{g} \mathrm{F}-\mathrm{g}$ and tissue accumulation is seldom greater than threefold except in extenuating circumstances such as kidney malfunction (Smith 1966b).

The majority $(90 \%+)$ of absorbed fluoride is sequestered in mammalian skeletons. Kay et al. (1975) reported femur levels of $148.7 \mu \mathrm{g} \mathrm{F}-/ \mathrm{g}$ in beaver and $266.4 \mu \mathrm{g} \mathrm{F} / \mathrm{g}$ in muskrat, even in uncontaminated environments. Primary deposition involves exchange with hydroxyl ions on the surface of the well-defined crystalline hydroxyapatite $\left(\mathrm{Ca}_{10}(\mathrm{OH})_{2}\left(\mathrm{PO}_{4}\right)_{6}\right)$ lattice, as $\mathrm{OH}^{-}$and $\mathrm{F}^{-}$are approximately the same size. At high exposure levels, phosphate may also be displaced. The same mechanisms are assumed to occur in fish, although in invertebrates the amorphous structure of the exoskeleton suggests simple deposition as $\mathrm{CaF}_{2}$ (Wright and Davison, 1975). Skeletal deposition does seem to have a saturation level in mammals, at 15,000 to $20,000 \mu \mathrm{g} \mathrm{F} / \mathrm{g}$. Beyond this point, almost $100 \%$ is excreted in the urine. When exposure ceases, skeletal mobilization shows a half-life of 2 or more years. Excretion rates reflect intake and show firstorder kinetics over time, although this is the culmination of a complex series of processes. Fluoride is filtered out in the glomeruli much like chloride, but is resorbed less efficiently. Faecal excretion is generally less than $10 \%$ and reflects the amount of insoluble fluoride ingested, although some re-release from the blood into the stomach does occur that contributes to the faeces (Hodge and Smith 1965).

Key point: Aquatic mammals accumulate fluoride in their skeletons and teeth and release it via the urine.

\section{Birds}

Birds are also capable of accumulating fluoride in their bones. Pelicans from a contaminated estuarine environment had 3,495 $\mu \mathrm{g} \mathrm{F}^{-} / \mathrm{g}$ (cited in Walton 1986). Carnivorous and omnivorous species have higher bone levels than herbivores, even in nonpolluted environments, suggesting biomagnification (Rose and Marier 1977). Black-crowned night herons living adjacent to a phosphate processing plant showed increasing skeletal fluoride concentrations with age, up to $6,042 \mu \mathrm{g} \mathrm{F} / \mathrm{g}$ ash weight and a correlated increase in tibiae diameter and decrease in wall thickness, suggesting excessive internal bone resorption (Henny and Burke 1990).

Four Antarctic penguin species which consume a krill diet of more than $200 \mathrm{mg}$ fluoride per day showed femur concentrations in the order of $10,000 \mu \mathrm{g} \mathrm{F} / \mathrm{g}$ dry mass and soft tissue concentrations of 2 to $10 \mu \mathrm{g} \mathrm{F}^{-} / \mathrm{g}$ dry mass. These penguins excreted most of the fluoride consumed. What was absorbed was effectively buffered by the skeleton, where it had a half-life of only 3 to 4 weeks (Culik and Adelung 1988; Machoy and Machoy-Mokrzyńska 1990).

Key point: Birds also accumulate fluoride in bones.

\section{Biotransformation}

A variety of food plants, forage crops and soil microorganisms are 
capable of incorporating air-borne fluoride into organic acids (Groth 1975). Amounts formed have been shown to be related to the ability of the plant to extract fluoride from the environment. Fluoroacetate is the most common compound formed (Miller et al. 1973). Fluoroacetate combines with oxaloacetic acid in the tricarboxylic acid cycle, an integral part of respiration in all organisms (Ward and Huskisson 1972). The fluorocitrate thus formed binds irreversibly with aconitase, the enzyme that normally dehydrates citric acid to cis-aconitic acid. Citric acid then accumulates, leading to hypocalcemia and eventually heart failure in animals (Amdur et al. 1991). Fluoroacetate has been used to exterminate insects and rabbits (Albert 1979) and is 15 times more toxic to humans than is sodium fluoride (Matsumura 1975). No information is available on fluoroacetate formation in aquatic microorganisms, algae or plants, but their low ability to absorb fluoride suggests that even if they are capable of the synthesis, insufficient quantities would be formed to be harmful to the animals that consume them.

Key point: There is no evidence of significant biotransformation processes in aquatic systems.

\section{Toxicity}

\section{Lethal Threshold}

\section{Terrestrial systems}

Inorganic fluoride compounds such as sodium fluoride (NaF), cryolite $\left(\mathrm{Na}_{3} \mathrm{AlF}_{6}\right)$ and sodium fluorosilicate $\left(\mathrm{Na}_{2} \mathrm{SiF}_{6}\right)$ have been used since the beginning of the century as insecticides, and cases of human poisoning from mistaken use of "roach powder" as a baking ingredient have occurred consistently throughout the years (Hodge and Smith 1965). The oral $\mathrm{LD}_{50}$ for humans is estimated at $75 \mathrm{mg} / \mathrm{kg}$ for sodium fluoride and $125 \mathrm{mg} / \mathrm{kg}$ for sodium fluorosilicate (Matsumura 1975). For mammals in general, the oral $\mathrm{LD}_{50}$ 's range from 20 to $100 \mathrm{mg} / \mathrm{kg}$ or a blood concentration of 8 to $10 \mathrm{ppm}$ (WHO 1985). On the relative scale presented in Amdur et al. (1991), this puts fluoride compounds in the "very" to "extremely" toxic range and equivalent to DDT in acute toxicity. Symptoms of acute poisoning in humans include nausea, vomiting and diarrhoea, muscle and heart fibrillation, spasm and some paralysis, respiratory and cardiac depression, leading to coma before death. Internal examination reveals extensive congestion and mucus accumulation in digestive and respiratory tracts and damage to mucous membranes, particularly the intestinal epithelium. Basically, the normal metabolism of the cells is blocked and cell membrane permeability altered (SBSC 1979). Symptoms of toxicity in field voles included a rapid fall in body weight, loss of physical condition, diarrhoea, excessive thirst and the presence of severe dental abnormalities (Boulton et al. 1994). The specific cause of death has not been identified, but may involve enzyme inhibitions, calcium complex 
formation, dehydration and electrolyte loss, specific organ injury, particularly in the kidney and nervous system, or a combination of all the noted physiological effects (Hodge and Smith 1965).

Free-living protozoa and rotifers are fairly resistant to fluoride intoxication, no acute toxicity being observed before $1,000 \mathrm{mg} \mathrm{F}$ - $/ \mathrm{L}$. Some decrease in movement and occasional cyst formation was observed in concentrations as low as $2 \mathrm{mg} \mathrm{F}$-/L, however (Wantland 1956). Microorganisms are also generally resistant to fluoride. Clarkson et al. (1989) showed no effect on nitrification of a concentrated industrial waste below $200 \mathrm{mg} \mathrm{F}^{-} / \mathrm{L}$, then increasing inhibition to a plateau level at $800 \mathrm{mg} \mathrm{F}^{-} / \mathrm{L}$. Yeasts during fermentation are sensitive to concentrations of $30 \mathrm{mg} \mathrm{F}-/ \mathrm{L}$ (Hodge and Smith 1965). Van Wensem and Adema (1991) demonstrated toxicity to soil microorganisms, as measured by the rate of nitrification in poplar litter, above $0.1 \mathrm{mg} \mathrm{F} / \mathrm{g}$ dry weight

Key points: (i) Fluoride falls in the "very" to "extremely" toxic range for terrestrial systems. (ii) Specific cause of death in acute toxicity is not clear. (iii) Microorganisms and protozoa are relatively resistant to fluoride poisoning.

\section{Aquatic systems}

Aquatic studies generally indicate a low degree of acute toxicity for fluoride. In the process of setting water quality standards for North Carolina, an extensive review of fluoride toxicity in fresh water was conducted (WQPB 1986). The studies were performed under widely varying conditions of $\mathrm{pH}$, temperature, hardness and duration of exposure. Lethal levels (generally $\mathrm{LC}_{50}$ 's) reported range from $2.7 \mathrm{mg} \mathrm{F}-/ \mathrm{L}$ for rainbow trout (the most sensitive species) and $98 \mathrm{mg} \mathrm{F}-/ \mathrm{L}$ for Daphnia magna to 900 $\mathrm{mg} \mathrm{F}^{-} / \mathrm{L}$ for frogs, and 123 to $1,900 \mathrm{mg} \mathrm{F}^{-} / \mathrm{L}$ for algae and aquatic plants. Data for rainbow and brown trout have been extracted from the report and are presented graphically in Fig. 2. An incipient lethal level (the concentration at which toxic effects may be expected over very long periods of exposure) has been determined by these authors as roughly $2.5 \mathrm{mg} \mathrm{F}-/ \mathrm{L}$.

More recent studies generally support the conclusions of the North Carolina report. Samecka-Cyerman and Kempers (1990) found a 48 hour $\mathrm{LC}_{100}$ of $400-450 \mathrm{mg} \mathrm{F}-/ \mathrm{L}$ for aquatic liverworts (Scapania undula$\mathrm{ta}$ ), but reported that $100 \mathrm{mg} \mathrm{F} / \mathrm{L}$ for 16 days was harmless. Mane and Gokhale (1990a) demonstrated $\mathrm{LC}_{50}$ 's between $430 \mathrm{mg} \mathrm{F}^{-} / \mathrm{L}$ and $600 \mathrm{mg} \mathrm{F-/L}$ for the bivalve Lamellidens marginalis, depending on the season. There was a less-than-twofold difference between $\mathrm{LC}_{0}$ and $\mathrm{LC}_{50}$ levels in this study. Five cladoceran invertebrates had $\mathrm{LC}_{50}$ 's from $83.2 \mathrm{mg} \mathrm{F}-/ \mathrm{L}$ to $353.6 \mathrm{mg} \mathrm{F}^{-} / \mathrm{L}$ (Hickey 1989). The aquatic larvae of five Spanish net-spinning caddisflies (Trichoptera) were more sensitive to fluoride, having 96 hour $\mathrm{LC}_{50}$ 's of 26.3 to $44.9 \mathrm{mg} \mathrm{F}$ - / (Camargo and Tarazona 1990; Camargo et al. 1992a). Three American caddifly species had 96 hour $\mathrm{LC}_{50}$ 's ranging from 17.0 to $42.5 \mathrm{mg} \mathrm{F}^{-} / \mathrm{L}$ (Camargo et al. 1992b). Time-related toxicity data for the two most sensitive caddisfly species have been extracted from those reports and are presented graphically in Fig. 3. Fingernail clams (Musculium trans- 


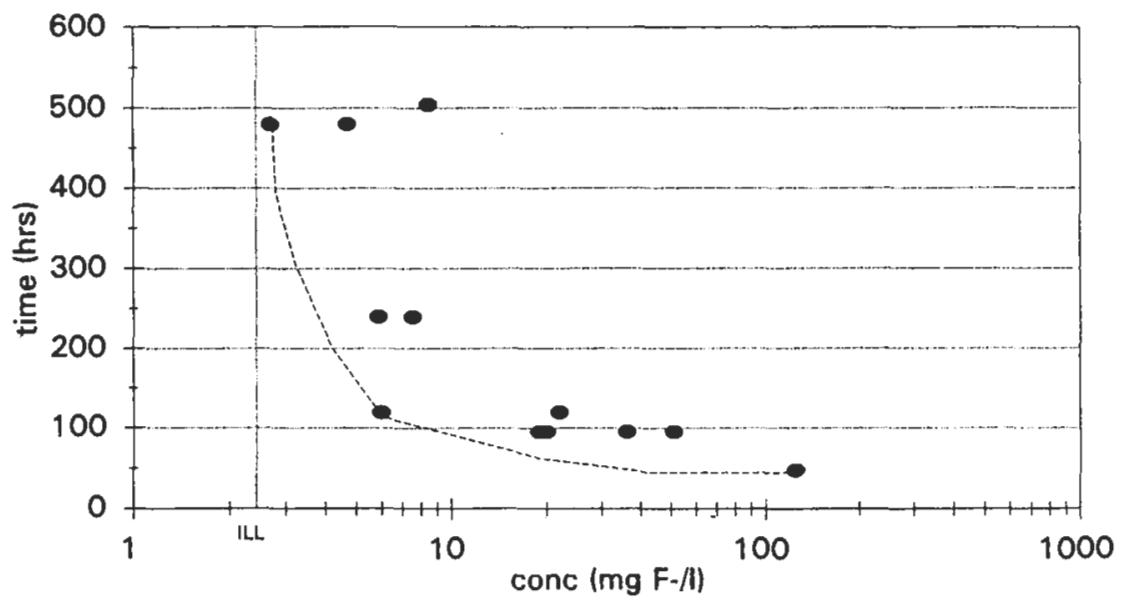

Fig. 2. The distribution of time-related lethal toxicity data for trout species, showing the apparent incipient lethal level (ILL). Data taken from WQPB (1986).

versum) are particularly sensitive, a $50 \%$ mortality rate being reported at a concentration of $2.8 \mathrm{mg} \mathrm{F} / \mathrm{L}$ in an 8-week flowthrough experiment (Government of Canada 1993).

The final acute value calculated for North American species and North Carolina water conditions in the WQPB study was $15.6 \mathrm{mg} \mathrm{F}$-/L,

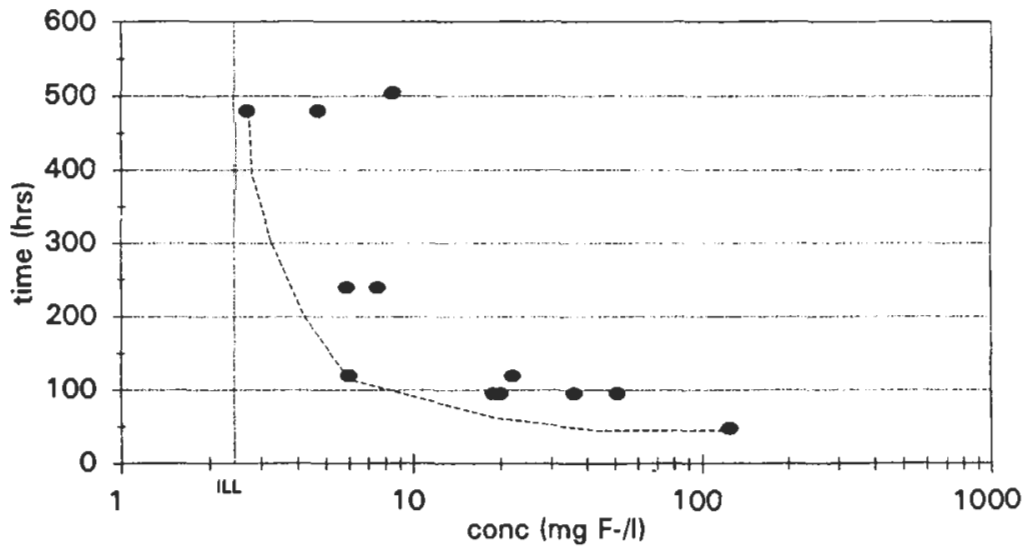

Fig. 3. The range of time-dependent EC50 and LC50 values and a calculated NOEC level for two sensitive species of Hydropsyche (caddisfly) aquatic larvae. Data are from Camargo et al. (1992a and b). 
roughly half the value used by the EPA when setting water quality standards in 1977. Camargo and Tarazona (1991) calculated a maximum acceptable toxic concentration (MATC) of $27.6 \mathrm{mg} \mathrm{F}-/ \mathrm{L}$ in soft water for rainbow trout. In general, acute fluoride toxicity increases with increasing temperature (Angelovic et al. 1961) and decreasing hardness (Pimental and Bulkley 1983). Given the relatively low temperatures and high hardness of the St. Lawrence River in the present study zone, lethal toxic effects due to fluoride would not be expected to occur even at the mouth of the treatment plant outlet. However, these "safe" values should be compared with those for chlorine, which was initially reported to be toxic to fish in the range of 100 to $1,000 \mathrm{mg} / \mathrm{L}$, but when chemical interactions with other materials in water were taken into account, the residual chlorine was shown to be acutely toxic at levels below $1 \mathrm{mg} / \mathrm{L}$. Total residual chlorine now has a recommended "likely long-term safe level" of $0.002 \mathrm{mg} / \mathrm{L}$ for continuous release into receiving fresh waters (Brungs 1973; Hellawell 1988). A similar change in "target" speciation may eventually occur for fluoride, particularly since Nichol et al. (1987) demonstrated that toxic effects on algae varied directly with the concentration of the hydrogen fluoride molecule, starting at $0.04 \mathrm{mg} / \mathrm{L}$.

Symptoms of fluoride poisoning in fish are apathy and loss of appetite, followed by violent sporadic movement, loss of equilibrium, muscle tremors and prolonged contraction, high mucous secretion and finally death (Neuhold and Sigler 1960; WHO 1985). These effects are sufficiently similar to those of mammals, birds (Andreasen and Stroud 1987) and insects to suggest a related toxic mechanism for all species.

Key points: (i) Fluoride ion is not very toxic to aquatic systems. (ii) The most sensitive aquatic organisms are certain pelagic fish species. (iii) Acute fluoride toxicity is greatest in warm, soft water.

\section{Sublethal Threshold}

\section{Terrestrial systems}

Effects of low doses of and chronic exposure to fluorides have been well studied in terrestrial animals (i.e., Suttie 1977). The major physiologic action is the alteration in dental and skeletal structure caused by the formation of fluoroapatite. Brittle, discoloured teeth, osteoporosis, lameness and postural changes result. Stiffness in the joints due to calcification of the tendons occurs. Loss of appetite, decreased mobility and difficulty chewing lead to weight loss and reduced productivity (WHO 1985; Boulton et al. 1994). Monsour and Kruger (1985) reviewed fluoride intoxication effects on soft tissues in vertebrates, noting the enigmatic nature of its actions and lack of specificity in tissues damaged and normal functions disrupted. The diagnosis of fluorosis cannot be made on any one symptom, but requires the correlation of urine, bone and tissue analyses, skeletal X-rays, biopsies and necropsies, and determination of fluoride levels in food consumed (SBSC 1979).

Plants exposed to low levels of fluoride exhibit chlorosis (yellowing) 
of leaves or needles, followed by tissue necrosis or leaf wilting. Eastern white pine (Pinus strobus) also showed reduced transpiration rates and changes in membrane permeability (Rakowski and Zwiazek 1992). Sensitive species may show reduced yield or decreased seed production, and some species experience altered growth rates, including increased but less healthy biomass production (Weinstein 1977; Canada 1993).

Key points: (i) Fluoride alters dental and skeletal structure, resulting in deformation and brittleness. (ii) Changes in membrane permeability are the initial effects of chronic fluoride exposure in plants.

\section{Aquatic systems}

When data gathered in the North Carolina report for sublethal effects and "no-observed-effect" concentrations (NOEC) are compared to those causing lethality, there does not appear to be a very significant difference. For example, the ratio of growth NOEC to $\mathrm{LC}_{50}$ for Daphnia magna is 0.11 (Fieser et al. 1986). Chronic:acute ratios calculated from data in the report range from 1.49 to 0.07 , and they recommend that an average value of 0.25 might be more accurate than the 0.05 rate used originally by the U.S.EPA, pending more appropriate and extensive chronic studies. SameckaCymerman and Kempers (1990) reported a chronic:acute ratio of 0.25 for aquatic liverworts. Hickey (1989) reported chronic:acute ratios of 0.14 and 0.17 for two Daphnia species. The ratio value of 0.05 is normally applied when insufficient chronic data exist to indicate otherwise and when bioaccumulation in an available form for food chain transfer does not occur to any significant degree. There remains a need for more careful study of chronic exposure effects in order to resolve the ratio issue, particularly as there is an indication that fluoride bioaccumulation occurs.

Sublethal toxicity can be difficult to quantify since the impact may only be observable at the population or community level. At the individual level generally studied in the laboratory, subtle changes in physiological parameters may go unnoticed or their significance unrecognized (Groth 1975). Nichol et al. (1987) suggested that a reduction in cellular ATP levels was responsible for the growth lag and inhibition of photosynthesis noted in cyanophyte algae exposed to between 5 and $150 \mathrm{mg} \mathrm{F}-/ \mathrm{L}$. The algae did eventually recover, however, and an ability to develop resistance to higher levels of fluoride was demonstrated, making the long-term effects of low-level fluoride exposure yet more difficult to discern.

Studies have been done on growth and reproductive effects of fluorides on Daphnia magna indicating an NOEC of $5.2 \mathrm{mg} \mathrm{F}^{-} / \mathrm{L}$ for standard test methods, but when the data were examined from a slightly different perspective, subtle reproductive effects were evident at concentrations as low as $0.4 \mathrm{mg} \mathrm{F}^{-} / \mathrm{L}$ (Dave 1984). The Indian bivalve Lamellidens marginalis exposed to non-lethal as well as lethal concentrations of fluoride showed significant changes in glycogen, protein and lipid contents in various body parts that reversed normal seasonal biochemical changes 
(Mane and Gokhale 1990b). Reddy and Venugopal (1990a, 1990b) have shown effects on protein metabolism, acetylcholinesterase activity and oxygen consumption of the Indian freshwater field crab Barytelphusa guerini at a sublethal fluoride level of $30 \mathrm{mg} \mathrm{F}$ / L. Equivalent work seems to be lacking for North American freshwater species, although Damkaer and Dey (1989) demonstrated an important impact of fluoride on Pacific salmon migratory patterns above $0.2 \mathrm{mg} \mathrm{F}-/ \mathrm{L}$. This is the concentration recommended by Foulkes and Anderson (1994) as the "criteria level" in fresh water to protect salmon species in the Pacific Northwest.

Ecotoxicological studies done on a Spanish river indicated that the release of a fluoride-containing industrial effluent contributed to only a minor degree to the elimination of rainbow and brown trout populations (Camargo 1991a) and alteration of caddisfly assemblages (Camargo 1991b) and macroinvertebrate communities (Camargo 1992) downstream. Levels of fluoride in the river were well below acute toxic levels, but above the calculated sublethal NOEC of $2.51 \mathrm{mg} \mathrm{F}-/ \mathrm{L}$ for sensitive caddisfly larvae (Camargo et al. 1992a) for $2.5 \mathrm{~km}$ below the outlet. A similar study in Colorado for a municipal wastewater fluoride source contributing to a level of $1.17 \mathrm{mg} \mathrm{F}^{-} / \mathrm{L}$ in the river also concluded that fluoride pollution was not a major factor in determining the spatial distribution and abundance of caddifly larvae (Camargo et al. 1992b). It is interesting to note that the sublethal $\mathrm{EC}_{50}$ values for the caddisfly larvae determined by Camargo et al. (1992a) fall in the same range as the lethal $\mathrm{LC}_{50}$ values presented in Fig. 3 . This would suggest that the critical endpoint to examine in terms of risk is the death of organisms, as there is little indication that sublethal and chronic effects are occuring at significantly lower concentrations.

Key points: (i) There is rarely a large difference between acute and chronic (or lethal and sublethal) threshold levels of fluoride in aquatic systems. (ii) There is some evidence to suggest that low levels of fluoride do not significantly alter aquatic community structures.(iii) Some species may exhibit avoidance behaviors that impact on reproductive success.

\section{Toxic Mechanisms}

\section{Enzymes and physiological processes}

Fluoride is a well-known enzyme inhibitor, often used to study enzyme action and structure, without relating the observed action to fluoride toxicity in whole organisms. Enzyme inhibition often has implications for survival and reproductive success at levels far below the lethal threshold. The capacity of fluoride to alter enzyme structure contributes to the concern about fluoride in the environment. As noted in the previous section, this may not be the case for fluoride in aquatic systems, but an examination of the subject is justified nonetheless. The interactions may involve $\mathrm{HF}$ and $\mathrm{HFF}^{-}$as well as $\mathrm{F}^{-}$, depending on the ambient $\mathrm{pH}$ employed in the experiment or expected in the tissue (Wiseman 1970). Emsley et al. (1981) pointed out the significance in biological systems of 
fluoride's ability to form strong hydrogen bonds with amides. Proteinbased compounds such as enzymes are dependent for their function on complex tertiary and quaternary structure maintained by hydrogen bonds between component amino acids and between amino groups and water molecules. For example, Edwards et al. (1984) demonstrated subtle alterations in the crystalline structure of yeast cytochrome $c$ peroxidase, due to the bonding of $\mathrm{HF}$ (at $20 \mathrm{mg} \mathrm{F}^{-} / \mathrm{L}$ ) to the iron at the heart of the enzyme, replacing a water molecule. The active site was disrupted by the attraction of two amino groups and the addition of a new water molecule, changing positions just enough to prevent the enzyme from bonding with cytochrome c. Wiseman (1970) presented a review of fluoride inhibitory action, primarily in mammalian cells and tissue extractions and homogenates, dividing the enzymes affected into four main groups: (1) requiring metal ions and enhanced by phosphate, i.e., enolase, phosphoglucomutase, lecithinase, succinic dehydrogenase; (2) requiring divalent metal ions, i.e., acid and alkaline phosphatases, pyrophosphatases, kinases, cholinesterase, glutamine synthetase, alcohol dehydrogenase; (3) no metal ions required, i.e., liver esterase or lipase, 5'-adenylic acid deaminase, phosphoglycerate mutase, hydrazidase; and (4) containing trivalent metal ions, i.e., catalase, peroxidase.

Additionally, Olson and Christensen (1982) report that levels of fluoride just above $1 \mathrm{mg} \mathrm{F}$ - $/ \mathrm{L}$ inhibit the activity of urease, an enzyme common in plants, algae, bacteria and microorganisms. Wilke (1987) reported decreases in the activity of dehydrogenases, alkaline phosphatases and aryl sulphatases in soil microorganisms exposed to low fluoride levels.

Although inhibition is much more commonly observed, fluorides may also activate enzymes. It is thought that this effect may be due to interference with the formation of larger carbohydrates, thus making more of the small substrate molecules available for metabolism. This situation induces higher activity of the appropriate enzymes (Hodge and Smith 1965). Also, when glycolysis is blocked by fluoride, the enzymes of the hexose monophosphate shunt are stimulated (Saralakumari and Ramakrishna 1991). The effects of fluoride on bone structure involve stimulation of osteoblast precursors to increase phosphate transfer across the plasma membrane, either by causing the synthesis of new $P_{i}$ carriers or speeding the turnover of existing ones (Selz et al. 1991).

Examination of fluoride effects on enzymes in aquatic organisms are rare, but two papers should be noted. Christensen (1971) found no effect on in vitro glutamic oxalacetic transaminase and lactic dehydrogenase from white sucker (Catostomus commersoni) blood plasma even at 2,000 $\mathrm{mg}$ $\mathrm{F}-/ \mathrm{L}$, although heavy metal cations with known aquatic toxicity showed effects at $50 \mathrm{mg} \mathrm{F}$-/L. Neither of these metabolic enzymes is known to have a metal cofactor as so many of the enzymes affected by fluoride do. Carbonic anhydrase, an enzyme that catalyses the transport of carbon dioxide from tissues to red blood cells and hence to water in the gills of channel catfish (Ictalurus punctatus), showed no effect below $20 \mathrm{mg} \mathrm{F}^{-} / \mathrm{L}$ in vitro (Christensen and Tucker 1976). 
Matthews (1970) attempted to put all these enzyme interactions into perspective by discussing changes in cell and tissue function as a consequence of fluoride intoxication. Metabolic pathways, physical activity, cell growth and cell development are all affected at some point. Adenosine triphosphate (ATP) stores the energy obtained from food and is essential for all energy-consuming cell activities. Without ATP, there is no life (Blaise et al. 1986).

The pathways affected by fluoride include (1) energy production by glycolysis, (2) pyruvate metabolism and oxidation, (3) oxidative phosphorylation, (4) respiration, (5) protein synthesis, (6) hormonal response, and (7) fat metabolism. Physical activity includes sperm motility, phagocytosis, contractility and transport across cell membranes. Ion balance in cells can be disrupted by inhibition of the sodium, potassium and calcium-dependent adenylate triphosphatases known as cation transport ATPases (i.e., Murphy and Hoover 1992). Coll and Murphy (1992) showed that the tight binding of two fluorides and one magnesium ion to the phosphorylation site of calcium ATPase blocks the transfer process. Calcium balance destroyed either through enzyme inhibition or direct precipitation of $\mathrm{CaF}_{2}$ can affect nerve transmission and blood coagulation and further disrupt cell permeability (SBSC 1979).

Key point: Fluoride is an effective enzyme inhibitor acting on a wide variety of internal systems.

\section{Mutagenicity}

Much has been made of the possible link between fluoride and cancer (i.e., Bundock et al. 1985). Studies indicating chromatid damage and chromosome abnormalities in vitro abound but are contradicted by others. Definite evidence has been presented regarding unscheduled DNA synthesis at exposure levels below $1 \mathrm{mg} \mathrm{F}^{-} / \mathrm{L}$ that support the concern regarding mutagenicity (Zeiger et al. 1993). Little extension to in vivo work seems to have occurred, however, particularly for aquatic species. Additionally, the fluoride levels used for many of the in vitro works were higher than those likely to be encountered in tissues of aquatic organisms living in water with a fluoride concentration of less than $1 \mathrm{mg} \mathrm{F}$ - $/ \mathrm{L}$.

In vitro inhibition of DNA repair mechanisms has been reported by some researchers at levels of 0.4 to $1.0 \mathrm{mg} \mathrm{F}-/ \mathrm{L}$ (SBSC 1979; WHO 1985). Although their direct carcinogenic action is questionable, the potential is present for fluorides to act as cofactors in the presence of known mutagens in that damage done by the other compounds would not be as readily corrected. More research is required to define the degree of potentiation that fluorides may be capable of producing. An extensive review of fluoride potential for genetic toxicity (Zeiger et al. 1993) concluded that the issue of chromosome damage in vivo was unresolved and that research was needed into possible mechanisms for observed effects, including the extent of $\mathrm{F}^{-}$interaction with DNA-associated proteins or enzymes.

Key point: Fluoride has not been clearly shown as directly carcino- 
genic but may be a cofactor.

\section{Synergisms}

\section{Aluminium}

As mentioned in the section on transport, the mobilization of aluminium in the presence of low concentrations of fluoride is a matter of environmental concern (Driscoll et al. 1980). Formation of fluoro-aluminium complexes does lower the toxicity of aluminium to juvenile Atlantic salmon (Salmo salar), but the complexes retain some toxic action (Wilkinson et al. 1990). The toxic mechanism of $\mathrm{Al}(\mathrm{F})_{\mathrm{x}}$, like that of aluminium alone, involves the upset of osmoregulation and the reduction in plasma sodium concentration, even at sublethal levels of $1.0 \mu \mathrm{M} / \mathrm{L}$. Parkhurst et al. (1990) showed no difference in aluminium toxicity to brook trout fry (Salvelinus fontinalis), despite an excess of fluoride ion available for complex formation with the aluminium. Work has generally been conducted in soft water at relatively low $\mathrm{pH}$, however, simulating conditions in the Canadian Shield, rather than the moderately hard, slightly alkaline conditions existing in the St. Lawrence River. The potential for ecological damage by fluoro-aluminium complexes remains to be confirmed in the receiving waters of the Montréal sewage treatment plant.

Of note regarding human consumption of fluoride is its ability to release aluminium from cooking utensils (Tennakone et al. 1988), notably in the presence of boiling fruit acids (Walton 1989). Once ingested and absorbed into the body, aluminium causes altered calcium metabolism in several tissues, including the brain, and is implicated in a number of neurological disorders, notably Alzheimer's disease (Amdur et al. 1991). Wei et al. (1995) suggested a combined toxicosis between fluoride and aluminium based on experiments with chickens, rabbits and rats, in an attempt to explain unusual symptoms observed in some human patients from a severe fluorosis region.

\section{Copper}

Research on the green algae Chlorella vulgaris has shown a cessation of respiration on joint application of fluoride and copper at concentrations that have no effect when applied separately (Hassall 1969; Sargent and Taylor 1972). Levels of both copper and fluoride were, however, 10 to 100 times greater than those existing in the St. Lawrence River (Sloterdijk 1988). It does not seem likely that the algal community that forms the base of the aquatic food chain is threatened by this synergism.

\section{Chloride}

Neuhold and Sigler (1960) cite a study indicating that fluoride toxicity increases for the mosquitofish (Gambusia affinis) in the presence of chlorine. This is in agreement with studies of halogen interactions on 
Chorella algae by Kott and Edlis (1969). However, work on rainbow trout indicates that chloride tempering decreases the response to a given concentration of fluoride, presumably due to the activation of chloridesecreting cells in the gills (Neuhold and Sigler 1962). Chloride levels of 3 to $48 \mathrm{mg} / \mathrm{L}$ (Sloterdijk 1988) in the St. Lawrence River may thus have a protective effect with respect to additional fluoride from the sewage outlet.

\section{Organic Compounds}

Studies on the effect of fluoride on the liver microsomal cytochromeP450 system that is often implicated in the metabolism of organic compounds are contradictory. Post and Snyder (1983) found that benzene metabolism was stimulated by fluoride concentrations greater than 10 $\mathrm{mM} / \mathrm{L}$. Do Phuoc et al. (1983) found that inhaled fluoride at $4 \mathrm{ppm}$ inhibited total cytochrome-P450 levels in rat liver, but induced dimethylnitrosamine-demethylase, thus increasing the cancerogenic potential of DMN. Bompart et al. (1988) reported no effect on benzo(a)pyrene metabolism due to inhaled HF. The metabolism of organic contaminants is a complex subject that requires further in-depth research before any conclusions can be drawn regarding possible synergisms with fluorides, but it appears that there is some potential for synergism with certain kinds of organic pollutants.

\section{Miscellaneous}

Marier (1972) and Weinstein (1977) note that the presence of boron in soil or applied fertilizers increases the uptake of fluoride by plants. The extent of this particular interaction is difficult to assess in the current situation, as boron content is not normally determined in Quebec waters and the applicability of the observed effect to aquatic plants is unknown.

Del Razo et al. (1993) noted the correlation between high arsenic and high fluoride concentrations in drinking water in an area of Mexico and suggested that some of the symptoms attributed to arsenic poisoning may be due to fluoride. Both elements affect enzyme activity in the glycolytic and tricarboxylic acid pathways, depress succinate dehydrogenase activity and disrupt heme synthesis.

The Alcan Surveillance Committee (ASC 1979) felt that there was a link between fluoride stress and susceptibility to insect infestation in trees near the Alcan smelter at Kitimat, B.C. This interaction is of the subtle type that is difficult to confirm in the laboratory and subject to a variety of interpretations when observed in the field. Similarly, combined effects of sulfur dioxide and fluoride air pollution have been reported in the field (Murray and Wilson 1988). Implications for aquatic systems are impossible to determine. Such occurrences are, however, consistent with the overall assumption that any new and foreign contaminant that an organism must deal with reduces its viability and reproductive capacity. 
Key point: The only significant evidence of synergistic action is with aluminium, in which the increased mobilization of aluminium may be balanced by the decreased toxicity of fluoro-aluminium complexes.

\section{Summary}

Water fluoridation by the city of Montréal would add only a small amount of fluoride to the St. Lawrence River as a whole, although it may be enough to push some kinds of organisms over sublethal thresholds in the immediate receiving waters. The small difference between no-effect and lethal levels of fluoride in aquatic systems is significant; lethality would appear to be the critical endpoint for risk assessment purposes. The physicochemical conditions of the river reduce the potential for lethal toxic action considerably. The existing community is relatively pollutiontolerant, and there are no behaviorally sensitive species like the Pacific salmon present that would be affected in the long term. Therefore, it is concluded that the fluoridation of the city of Montréal's drinking water would pose only a minimal risk to the aquatic community in the immediate receiving waters of the St. Lawrence River, due to a minor additional stress to enzyme systems within the few organisms present. Should the city decide to fluoridate, a biomonitoring program is recommended, measuring the activities of a few target enzymes in the benthic species present.

\section{Acknowledgments}

Funding for this work was provided initially by the City of Montréal. We wish to thank Normand Brunet (conseiller en planification, Ville de Montréal) in particular for his support. Further funding was provided by the Natural Sciences and Engineering Research Council (NSERC) through a research grant to R. Gehr.

\section{References}

Albert, A. 1979. Selective toxicity, 6th ed. Chapman and Hall, London.

Amdur, M.O., J. Doull, and C.D. Klassen. (ed.) 1991. Casarett and Doull's toxicology: the basic science of poisons, 4th ed. McGraw-Hill, New York.

Andreasen, J.K. and R.K. Stroud. 1987. Industrial halide waters cause acute mortality of snow geese in Oklahoma. Environ. Toxicol. Chem. 6:291-293.

Andrews, S.M., J.A. Cooke and M.S. Johnson. 1989. Distribution of trace element pollutants in a contaminated ecosystem established on metalliferous fluorspar tailings. 3: Fluoride. Environ. Poll. 60:165-179.

Angelovic, J.W., W.F. Sigler and J.M. Neuhold. 1961.Temperature and fluorosis in rainbow trout. J. Water Poll. Control Fed. 33:371-381.

ASC. 1979. Environmental effects of emissions from the Alcan smelter at Kitimat, B.C. Alcan Surveillance Committee, B.C. Min. Env., Victoria. 
Baars, A.J., H. van Beek, Th.J. Spierenburg, G.J. de Graf, W.G. Beeftink, J. Nieuwenhuize, J. Boom and J.J. Pekelder. 1987. Fluoride pollution in a salt marsh: Movement between soil, vegetation, and sheep. Bull. Environ. Contam. Toxicol. 39:945-952.

Bank, R.E. and H. Goldwhite. 1966. Fluorine chemistry, p.1-52. In F.A. Smith (ed.), Handbook of experimental pharmacology, vol. 20, part I. SpringerVerlag, New York.

Barbaro, A., A. Francescon and B. Polo. 1981. Fluoride accumulation in aquatic organisms in the lagoon of Venice. Fluoride 14(3):102-107.

Belair, M. and D.J. Viau. 1988. Cinquante ans d'engueulade. Guide Res. juilletaoût, 16-19.

Blaise, C., B. Trottier, R. Van Coillie and P. Couture. 1986. Evaluation de la toxicité sublétale des effluents industriels vis-à-vis du poisson en mesurant l'ATP du muscle squelettique. Water Poll. Res. J. Can. 21(1):71-90.

Bompart, G., J. Rakotoarivony and Y. Manuel. 1988. Liver and lung aryl hydrocarbon hydroxylase activity in benzo(a)pyrene treated rats: lack of effect of HF. Fluoride 20(1):5-7.

Boulanger, F. 1984. Station d'épuration de la CUM: Repercussions environnementales d'un déversement d'eaux prétraitées à l'émissaire de l'lle aux Vaches. Rapport d'étude LHL-901. Communaute urbain de Montréal, Montréal.

Boulton I.C., J.A. Cooke and M.S. Johnson. 1994. Experimental fluoride accumulation and toxicity in the short-tailed field vole (Microtus agrestis). J. Zool. Lond. 234:409-421.

Brungs, W.A. 1973. Effects of residual chlorine on aquatic life. J. Water Poll. Control Fed. 45:2180-2193.

Bundock, J.B., D. Burk, J.R. Graham and P.J. Morin. 1985. Environmental health: Fluorides, water fluoridation, cancer and genetic diseases. Sci. Pub. Pol. 12(1):36-46.

Bundock, B., J.R., Graham and P.J. Morin. 1982. Water fluoridation: fluorides, water fluoridation and environmental quality. Sci. Pub. Pol. 9:130-142.

Buse, A. 1986. Fluoride accumulation in invertebrates near an aluminium reduction plant in Wales. Environ. Poll. A41:199-217.

Camargo, J.A. 1991a. Ecotoxicological analysis of the influence of an industrial effluent on fish populations in a regulated stream. Aquacult. Fish. Manage. 22(4):509-518.

Camargo, J.A. 1991b. Ecotoxicological study of the influence of an industrial effluent on a net- spinning caddisfly assemblage in a regulated river. Water Air Soil Poll. 60:263-277.

Camargo, J.A. 1992. Macroinvertebrate responses along the recovery gradient of a regulated river (Spain) receiving an industrial effluent. Arch. Environ. Contam. Toxicol. 23:324-332.

Camargo, J.A., D. Garcia de Jalon, M.J. Muñoz and J.V. Tarazona. 1992a. Sublethal effects of sodium fluoride $(\mathrm{NaF})$ on net-spinning caddisflies (Trichoptera). Aquatic Insects 14(1):23-30.

Camargo, J.A. and J.V. Tarazona. 1990. Acute toxicity to freshwater benthic macroinvertebrates of fluoride ion (F) in soft water. Bull. Environ. Contam. Toxicol. 45:883-887.

Camargo, J.A. and J.V. Tarazona. 1991. Short-term toxicity of fluoride ion (F-) in soft water to rainbow trout (Salmo gairdneri) and brown trout (Salmo trutta fario). Fluoride 24(2):76-83.

Camargo, J.A., J.V. Ward and K.L.Martin. 1992b. The relative sensitivity of competing hydropsychid species to fluoride toxicity in the Cache la Poudre 
River (Colorado). Arch. Environ. Contam. Toxicol, 22:107-113.

CCE. 1986. Fluorures d'origine industrielle dans l'environnement québécoise. Tome I, II, III. Conseil consultatif de l'environnement, Min. Env. Que., Quebec.

Chaisemartin, C. 1985. Aspect des phénomènes de bioaccumulation et de transfert des fluorures dans les milieux dulcaquicoles perterbés. Rev. Fran. Sci. Eau. 4(1):17-34.

Choueiri, N.F., P. Béron and R. Gehr. 1995. Fluoride in urban wastewater: seasonal variations and mass balances. Submitted to Can. J. Civil Eng.

Christensen, B. 1987. Uptake and release of fluoride in Artic char. Environ. Tox. Chem. 6(7):529-533.

Christensen, G.M. 1971. Effects of metal cations and other chemicals upon the in vitro activity of two enzymes in the blood plasma of the white sucker, Catostomus commersoni (Lacepede). Chem.-Biol. Inter. 4:351-361.

Christensen, G.M. and J.H. Tucker. 1976. Effects of selected water toxicants on the in vitro activity of fish carbonic anhydrase. Chem.-Biol. Inter. 13:181-192.

Chu, V.H., R. Gehr and R. Leduc. 1991. Dilution of MUC wastewater treatment plant effluent in the St. Lawrence River. Proceedings of the 1991 Annual Conference of the Canadian Society for Civil Engineering, Vancouver.

Clarkson, W.W., A.G. Collins and P.L. Sheehan. 1989. The effect of fluoride on nitrification of a concentrated industrial waste. Appl. Environ. Micro. 55(1):240-245.

Coll, R.J. and A.J. Murphy. 1992. Fluoride-inhibited calcium ATPase of sarcoplasmic reticulum: Magnesium and fluoride stoichiometry. J. Biol. Chem. 267(30):21584-21587.

Colquhoun, J. 1994. Is there a dental benefit from water fluoride? Fluoride 27(1):13-22.

Culik, B. and D. Adelung. 1988. Fluoride toxicity in Antarctic penguins: problems associated with a krill diet. Cormorant 16:124-125.

Damkaer, D.M. and D.B. Dey. 1989. Evidence for fluoride effects on salmon passage at John Day Dam, Columbia River, 1982-1986. N. Am. J. Fish. Manage. 9:154-162.

Dave, G. 1984. Effects of fluoride on growth, reproduction and survival of Daphnia magna. Compar. Biochem. Physiol. C78(2):425-431.

Davies, K. 1989. Personal communication. Toronto Environmental Protection Office.

Del Razo, L.M., J.C. Corona, G. Garcia-Vargas, A. Albores and M.E. Cebrián. 1993. Fluoride levels in well-water from a chronic arsenicism area of northern Mexico. Environ. Poll. 68:91-94.

Diercksen, G., W.P. Kraemer and B.O. Roos. 1975 SCF-CI studies of correlation effects on hydrogen bonding and ion hydration. The systems: $\mathrm{H}_{2} \mathrm{O}, \mathrm{H}+. \mathrm{H}_{2} \mathrm{O}$, $\mathrm{Li}+\mathrm{H}_{2} \mathrm{O}, \mathrm{F}-. \mathrm{H}_{2} \mathrm{O}$ and $\mathrm{H}_{2} 0 . \mathrm{H}_{2} \mathrm{O}$. Theoret. Chim. Acta 36:249-274.

Do Phuoc, H., G. Bompart, P. Bourbon and L. Bouteille. 1983 Action du F- sur le metabolisme hepatique de la dimethylnitrosamine et du benzo(a)pyrene chez le rat. Toxicol. Eur. Res. 5(1):31-35.

Driscoll, C.T. Jr., J.P. Baker, J.J. Bisogni Jr. and C.L. Schofield. 1980. Effect of aluminium speciation on fish in dilute acidified waters. Nature 284:161-164.

Edwards, S., T. Poulos and J. Kraut. 1984. The crystal structure of fluoride-inhibited cytochrome c peroxidase. J. Biol. Chem. 259(21):12984-12988.

Elrashidi, M.A. and W.L. Lindsay. 1987 Effect of fluoride on $\mathrm{pH}$, organic matter and solubility of elements in soils. Environ. Poll. 47(2):123-134. 
Emsley, J., D.J. Jones, J.M. Miller, R.E. Overhill and R.A. Waddilove. 1981. An unexpectedly strong hydrogen bond: ab initio calculations and spectroscopic studies of amide-fluoride systems. J. Am. Chem. Soc. 103(1):24-28.

Fieser, A.H., J.L. Sykora, M.S. Kostalos, Y.C. Wu and D.W. Weyel. 1986. Effect of fluorides on survival and reproduction of Daphnia magna. J. Water Poll. Control Fed. 58(1):82-86.

Foulkes, R.G. and A.C. Anderson. 1994. Impact of artificial fluoridation on salmon species in the northwest USA and British Columbia, Canada. Fluoride 27(4):220-226.

Gehr, R. and R. Leduc. 1992. Assessing effluent fluoride concentrations following physicochemical wastewater treatment. Can. J. Civil Eng. 19(4):649-659.

Gibson, J.A.E., I.R. Willet and W.J. Bond. 1992. The effects of sulphate and fluoride on the sorption of aluminium by an oxisol. J. Soil Sci. 43:429-439.

Gikunju, J.K. 1992. Fluoride concentration in tilapia fish (Oreochromis leucostictus) from Lake Naivasha, Kenya. Fluoride 25(1):37-43.

Gordon, C.C. and P.C. Tourangeau. 1977. Fluoride accumulation in the terrestrial and aquatic components of the Douglas Creek drainage of western Montana. Rep. \#91. Montana Joint Water Resources Research Centre, Bozeman, Mont.

Government of Canada. 1993. Canadian Environmental Protection Act. Inorganic fluorides (Priority Substances List Assessment Report). En 40-215/32E, Government of Canada, Environment Canada, Health Canada, Ottawa.

Gravel, Y. and G. Pageau. 1979. Les ressources biologiques et récréatives du SaintLaurent, sont-elles inépuisables? L'Ingénieur 314(3):21-36.

Groth, E. 1975. An evaluation of the potential for ecological damage by chronic low-level environmental pollution by fluoride. Fluoride 8(4):224-240.

Hassall, K. 1969. An asymmetric respiratory response occuring when fluoride and copper ions are applied jointiy to Chlorella vulgaris. Physiol. Plant 22:304-311.

Hellawell, J.M. 1988. Toxic substances in rivers and streams. Environ. Poll. 50:61-85.

Hemens, J. and R.J. Warwick. 1972. The effects of fluoride on estuarine organisms. Water Res. 6:1301-1308.

Henny, C.J. and P.M. Burke. 1990. Fluoride accumulation and bone strength in wild black-crowned night herons. Arch. Environ. Contam. Toxicol. 19:132-137.

Hickey, C.W. 1989. Sensitivity of four New Zealand cladoceran species and Daphnia magna to aquatic toxicants. New Zealand J. Marine Fresh. Res. 23:131-137.

Hodge, H.C. and F.A. Smith. 1965. Biological properties of inorganic fluorides. In J.H. Simons (ed.), Fluorine chemistry, vol. IV. Academic Press, New York.

Hubbs, C.L. and K.F. Lagler. 1964. Fishes of the Great Lakes Region. University of Michigan Press, Ann Arbor, Mich.

Kay, C.E., P.C. Tourangeau and C.C. Gordon. 1975. Fluoride levels in indigenous animals and plants collected from uncontaminated ecosystems. Fluoride 8(3):125-133.

Kott, Y. and J. Edlis. 1969. Effect of halogens on algae. I. Chlorella sorokiniana. Water Res. 3:251-256.

Kudo, A. and J.P. Garrec. 1983. Accidental release of fluoride into experimental pond and accumulation in sediments, plants, algae, molluscs and fish. Reg. Tox. Pharm. 3:189-198.

Landy,R.B., R.H. Lambertsen, P.A. Palsson, L. Krook, A. Nevius and R. Eckerlin. 1991. Fluoride in the bone and diet of fin whales, Balaenoptera physalus. Mar. Environ. Res. 31:241-247. 
Machoy, Z. and A. Machoy-Mokrzyńska. 1990. Mechanisms of fluoride elimination and detoxification in living organisms. Fluoride 23(4):151-153.

Mane, U.H. and A.A. Gokale. 1990a. Acute toxicity of fluoride and changes in respiration of the bivalve, Lamellidens marginalis (Lamarck) from Godivari River near Aurangabad. Abstract 12th Annual Conference on Physiological and Biochemical Approaches to the Toxicological Assessment of Environmental Pollution, Utrecht, Netherlands.

Mane, U.H. and A.A. Gokale. 1990b. Biochemical changes due to acute toxicity of fluoride to the bivalve, Lamellidens marginalis (Lamarck) from Godivari River near Aurangabad. Abstract 12th Annual Conference on Physiological and Biochemical Approaches to the Toxicological Assessment of Environmental Pollution, Utrecht, Netherlands.

Mane, U.H. and K.S. Pillai. 1985. Fluoride in Godvari River at Paithan, Marathwada, Maharashtra State. Fluoride 18(1):12-14.

Marier, J.R. 1972. The ecological aspect of fluoride. Fluoride 5:92-97.

Masuda, T.T. 1964. Persistence of fluoride from organic origins in waste waters. Dev. Indus. Micro. 5:53-70.

Matsumura, F. 1975. Toxicology of Insecticides. Plenum Press, New York.

Matthews, J. 1970. Changes in cell function due to inorganic fluoride, p. 98-143. In F.A. Smith (ed.), Handbook of experimental pharmacology, vol. 20, part II. Springer-Verlag, New York.

McClurg, T.P. 1984. Effects of fluoride, cadmium and mercury on the estuarine prawn Penaeus indicus. Water S.A. 10(1):40-45.

Miller, G.W., M.H. Yu and M. Psenal. 1973. Presence of fluoroorganic compounds in higher plants. Fluoride 6(4):203-215.

Monsour, P.A. and B.J. Kruger. 1985. Effect of fluoride on soft tissues in vertebrates: A review. Fluoride 18(1):53-61.

Moolenburg, H. 1987. Fluoride: the freedom fight. Mainstream Pub., Edinburg.

Moore, D.J. 1971. The uptake and concentration of fluoride by the blue crab, Callinectes sapidus. Chesapeake Sci. 12:1-13.

Murphy, A.J. and J.C. Hoover. 1992. Inhibition of the Na,K-ATPase by fluoride. J. Biol. Chem. 267(24):1695-1700.

Murray, F. and S. Wilson. 1988. The joint action of sulphur dioxide and hydrogen fluoride on the yield and quality of wheat and barley. Environ. Poll. 55:239-249.

Neal, C. 1989. Fluorine variations in Welsh streams and soil waters. Sci. Tot. Environ. 80(2-3):213-223.

Neuhold, J.M. and W.F. Sigler. 1960. Effects of sodium fluoride on carp and rainbow trout. Trans. Am. Fish. Soc. 89:358-370.

Neuhold, J.M. and W.F. Sigler. 1962. Chlorides affect the toxicity of fluorides to rainbow trout. Science 135:732-733.

Nicol, B.E., K. Budd, G.R. Palmer and J.D. MacArthur. 1987. The mechanisms of fluoride toxicity and fluoride resistance in Synechococcus leopoliensis (Cyanophyceae). J. Phycol. 23(4):535-541.

Nopakum, J. and H.H. Messer. 1990. Mechanism of fluoride absorption from the rat small intestine. Nut. Res. 10:771-779.

Olson, D.L. and G.M. Christensen. 1982. Effect of selected environmental pollutants and other chemicals on the activity of urease (in vitro). Bull. Environ. Contam. Toxicol. 28:439-445.

Ouellet, M., H.G. Jones and G. Bernier. 1983. Contamination de la neige par les émissions atmosphériques de fluorures d'alumineries. Sci. Tech. Eau 16(4):343-348. 
Parkhurst, B.R., H.L. Bergman, J. Fernandez, D.D. Gulley, J.R. Hockett and D.A. Sanchez. 1990. Inorganic monomeric aluminum and $\mathrm{pH}$ as predictors of acidic water toxicity to brook trout (Salvelinus fontinalis). Can. J. Fish. Aquat. Sci. 47:1631-1640.

Pascoe, G.A. 1993. Wetland risk assessment. Environ. Toxicol. Chem. 12(12):2293-2307.

Patterson, J.W. 1985. Industrial wastewater treatment technology, 2nd ed. p. 135153. Butterworth Pub., Toronto.

Peterson, R.T. 1980. A Field guide to the birds, 4th ed. Houghton Mifflin Co., Boston.

Pickering, W.F. 1985. The mobility of soluble fluoride in soils. Environ. Poll. B9:281-308.

Pickering, W.F., J. Slavek and P. Waller. 1988. The effect of ion exchange on the solubility of fluoride compounds. Water Air Soil Poll. 39:323-336.

Pillai, K.S. and U.H. Mane. 1984. The effect of fluoride on fertilized eggs of a freshwater fish, Catla calla (Hamilton). Tox. Letter 22(2):139-144.

Pillai, K.S. and U.H. Mane. 1985. Effect of fluoride effluent on fry of Catla catla (Hamilton). Fluoride 18(2):104-110.

Pilon, C., J.M. Boisvert, D. Carriere, J. Champagne, P. Chevalier, D. LeQuere, V. Sicard and G. Sylvain. 1980. Les îles du Saint-Laurent, de Boucherville à Contrecoeur: Environnement biophysique. Vol. I,II. Centre de recherches écologiques de Montréal, U. Montréal.

Pimental, R. and R.V. Bulkley. 1983. Influence of water hardness on fluoride toxicity to rainbow trout. Environ. Toxicol. Chem. 2(4):381-386.

Post, G.B. and R. Snyder. 1983. Fluoride stimulation of microsomal benzene metabolism. J. Toxicol. Environ. Health 11:799-810.

Rakowski, K.J. and J.J. Zwiazek. 1992. Early effects of hydrogen fluoride on water relations, photosynthesis and membrane integrity in eastern white pine (Pinus strobus) seedlings. Environ. Exp. Bot. 32(4):377-382.

Reddy, S.L.N. and N.B.R.K. Venugopal. 1990a. Fluoride induced changes in protein metabolism in the tissues of freshwater crab Barytelphusa guerini. Environ. Poll. 67:97-108.

Reddy, S.L.N. and N.B.R.K. Venugopal. 1990b. Effect of fluoride on acetylcholinesterase activity and oxygen consumption in a freshwater field crab, Barytelphusa guerini. Bull. Environ. Contam. Toxicol. 45:760-766.

Rose, D. and J.R. Marier. 1977. Environmental fluoride. Environment Canada NRCC Report \#16,081, Ottawa.

Samecka-Cymerman, A. and A.J.Kempers. 1990. Tolerance of Scapania undulata (L.)Dum. to fluoride. Aquat. Bot. 37:163-170.

Saralakumari, D.R. and P. Ramakrishna. 1991. Red blood cell glucose metabolism in human chronic fluoride toxicity. Bull. Environ. Contam. Toxicol. 47:834-839.

Sargent, D.F. and C.P.S. Taylor. 1972. The effect of cupric and fluoride ions on the respiration of Chlorella. Can. J. Botany 50:905-907.

SBSC. 1979. Critère à l'appui d'une norme relative à la teneur en fluorures de l'eau de boisson. L'Association canadiene d'hygiene publique. Min. de la Santé et du Bien-être social Canada, Ottawa. Rep.\#80-EHD-49.

Selz, T., J. Caverzasio and J.-P. Bonjour. 1991. Fluoride selectively stimulates Nadependent phosphate transport in osteoblast-like cells. Am. J. Physiol. 260(1): E833-838.

Shaikh, Y.A. 1986. Studies on fluoride uptake by soft tissues of an edible mud- 
skipper, Boleophthalmus dussumieri of Dumas Coast, Gujarat. Fluoride 19(3): 121-123.

Shirke, P.A. and P. Chandra. 1991. Fluoride uptake by duck-weed Spirodela polyrrhiza. Fluoride 24(3):109-113.

Slavek, J., H. Farrah and W.F. Pickering. 1984. Interaction of clays with dilute fluoride solutions. Water Air Soil Poll. 23:209-220.

Sloterdijk, H. 1988. Unpublished data on surface water and sediment contaminants on NAQUADAT. St. Lawrence Centre, Montréal.

Smith, F.A. (ed.) 1966a. Pharmacology of fluorides. Handbook of experimental pharmacology, vol. 20, Part I. Springer-Verlag, New York.

Smith, F.A. 1966b. Metabolism of inorganic fluoride, p. 53-140. In F.A. Smith (ed.), Handbook of experimental pharmacology, vol. 20, part I. Springer-Verlag, New York.

Smith, F.A. (ed.) 1970. Pharmacology of fluorides. Handbook of experimental pharmacology, vol. 20, Part II. Springer-Verlag, New York.

Suttie, J.W. 1977. Effects of fluoride on livestock. J. Occup. Med.19(1):40-48.

Tennakone, K., S. Wickramanayke and C.A.N. Fernando. 1988. Aluminium contamination from fluoride-assisted dissolution of metallic aluminium. Environ. Poll. 49(2):133-144.

Van Wensem, J. and T. Adema. 1991. Effects of fluoride on soil fauna mediated litter decomposition. Environ. Poll. 72(3):239-251.

Ville de Montréal. 1988. Consultation publique sur le projet de fluoration de l'eau de consommation de la Ville de Montréal, vol. I, II. Rapport de la Commission permanente du Développement Communautaire.

Walton, K.C. 1986. Fluoride in moles, shrews and earthworms near an aluminium reduction plant. Environ. Poll. A42:361-371.

Walton, K.C. 1989. Effect of fluoride on the amount of aluminium dissolved by boiling fruit acids. Environ. Poll. 60:223-233.

Wantland, W.W. 1956. Effect of various concentrations of sodium fluoride on parasitic and free-living protozoa and rotifera. J. Dent. Res. 35:763-772.

Ward, P.F.V. and N.S. Huskisson. 1972. The metabolism of fluoroacetate in lettuce. Biochem. J. 130:575-587.

Weast, R.C. (ed.) 1984. CRC handbook of chemistry and physics. CRC Press, Boca Raton, Fla.

Wei, Z.D., F. Li, L. Zhou, X. Chen and G. Dai. 1995. Studies on fluoride-aluminum combined toxicosis. Fluoride 28(1):37-38.

Weinstein, L.H. 1977. Fluoride and plant life. J. Occ. Med. 19(1):49-78.

Whitford, G.M. and D.H. Pashley. 1984. Fluoride absorption: The influence of gastric acidity. Calcif. Tissue. Int'l. 36(3):302-307.

WHO. 1985. Fluor et fluorures. Critère d'hygiene de I'environnement, vol. 36. Organisation mondiale de la Santé, Genève.

Wilke, B.M. 1987. Fluoride-induced changes in chemical properties and microbial activity of mull, moder and mor soils. Biol. Fertil. Soils 5(1):49-55.

Wilkinson, K.J., P.G.C. Campbell and P. Couture. 1990. Effect of fluoride complexation on aluminum toxicity towards juvenile Atlantic salmon (Salmo salar). Can. J. Fish. Aquat. Sci. 47:1446-1452.

Wiseman, A. 1970. Effect of inorganic fluoride on enzymes, p. 48-97 In F.A. Smith (ed.), Handbook of experimental pharmacology, vol. 20, part II. SpringerVerlag, New York.

WQPB. 1986. North Carolina water quality standards documentation: toxicity of fluoride to freshwater biota. Water Quality Planning Branch, Div. Env. 
Manage., N.C. Dept. Nat. Res. Commun. Devel. Rep. \#86-01.

Wright, D.A. 1977. Toxicity of fluoride to brown trout fry (Salmo trutta). Environ. Poll. 12:57-62.

Wright, D.A. and A.W. Davison. 1975. The accumulation of fluoride by marine and intertidal animals. Environ. Poll. 8:1-13.

Wright, E.M. and J.M. Diamond. 1977. Anion selectivity in biological systems. Physiol. Reviews 57(1):109-156.

Zeiger, E., M.D. Shelby and K.L. Witt. 1993. Genetic toxicity of fluoride. Environ. Mol. Mutagen. 21:309-318. 